\title{
Detection of the piping processes analyzed through the Self Potential method, in the peripheral area of the Dognecei Mountains
}

\author{
Petru URDEA ${ }^{1 *}$, Alin ȚAMBRIȘ ${ }^{1}$ \\ ${ }^{1}$ West University of Timișoara, Department of Geography, 4 V. Pârvan Blvd., 300223, Timișoara, Romania \\ Received 13 November 2019; Revised 29 November 2019; Accepted 2 December 2019 \\ *Correspondence to: Petru URDEA e-mail: petru.urdea@e-uvt.ro
}

\begin{abstract}
The water movement in the soil contributes to entrainment of particles of varying sizes and, over time, some tendency for the orientation of this flow may occur. In the areas with particular soil characteristics, an internal discrete drainage network appears, that manifests differently depending on the causative factors. The aim of the recording and monitoring of this concentrated water flow movement that contributes to soil erosion as a discrete pipe network through a geophysical method is that of understanding his evolution. Using a method such as the Self Potential (SP) allows the study of the piping processes in a quantitative manner. In the peripheral area of the Dognecei Mountains, specifically near Doclin village, it was analyzed one such area in which this process occurs. It was analyzed the evolution of a site in periods with different climatic parameters which are the ones that function as the active elements. The amplitude of the SP values $(\mathrm{mV})$ differs depending on the causative environmental factors, with negative values in the dry period and positive values when the soil is wet, the values having fluctuation up to $15 \mathrm{mV}$. The piping processes contribute to soil degradation and the knowledge of the areas affected by these processes and particularly of the factors that influence its occurrence, with good results, by using the Self Potential method can be achieved.
\end{abstract}

KEYWORDS

Self Potential; piping; soil erosion; water movement; Dognecei Mountains; Romania

\section{Introduction}

The soil erosion depends on many factors, and this can occur both at the soil surface and internally, in the form of piping processes caused by water movement in soil as a linear network (Anthony and
Jones, 2004), contributing to the creation of an underground pipe network.

Piping is a subterranean erosion - a kind of subcutaneous erosion - defined as a process initiated by percolating waters which remove solid particles from clastic (fragmental) rocks to produce tubular 
underground conduits (Mears, 1968). Soil piping depends on numerous factors including soils and lithology, topography, climatic conditions, vegetation and land management. Due to the discrete manifestation of the subsurface nature of this process, piping morphological effects cannot be easily detected.

The piping processes appear mostly in the areas with steeper gradients through internal stress, but their presence is proved in the areas where the slope gradient is up to $12^{\circ}$ (Bernatek, 2015). Our interest about this hidden, discreetly geomorphological phenomenon is connected to the fact that the detection and evaluation of piping potential are currently limited (Richard and Raddy, 2007).

An important component of soil erosion is related to the land use in mountainous areas where the vegetative associations are predominant (Anțilă, 2012; Rusu, 2013). In the areas with low gradient are mentioned agricultural practices of the XVIII ${ }^{\text {th }}$ century, practices that widened since 1962, when forced socialization of agriculture is imposed (Medeleţ, 2005). In the contact area between the mountain area and the Doclin Hills, the soil surveys emphasized the pedogeopraphical characteristics, aspects structured in the studies of Ianoş and Pușcă (1998). The mining impact on water quality in the mountain area was presented by Marinică and Borza (2010).

All these anthropogenic changes in the landscape are essential and favor the soil erosion in various forms. This area was included in a study that had as a goal "The identification and delineation of natural hazards (earthquakes, landslides and floods)" in the territory of the county, and the study had as beneficiary the Ministry of Regional Development and Tourism. In this study it was determined that the Doclin area corresponds to a medium to large risk of landslides occurrence.

In the specialized literature the relations between the land erosion as a process and the factors that contribute to its accelerating or cessation are discussed, so that Nunes et al. (2011) address how different plant associations and ways of land use influence soil erosion and surface runoff. Similar studies were conducted by Alewell et al. (2008) and Warsta et al. (2013), these aimed at describing and predicting the soil erosion in mountainous areas.
Faulkner (2013), studied the scattering of the soils and the subsurface erosion and analyzed the stages of occurrence of the piping processes; the analysis of the factors that lead to soil erosion due to piping process and the emergence of the rills surface was made by Flores-Berones et al. (2011), Verachtert et al. (2011), Schuppener (2013) or Jacobson (2013) considering that the slope gradient, the drainage area, the curvature, the surface aspect, the soil type and the lithology, to which are added the mechanical and chemical action of the water, have a major role. Other factors associated with the piping processes are the soil erosion coefficient, internal stress, or the time (Bonelli and Benahmed, 2010).

By knowing the factors that might influence the internal soil erosion, we can establish to a certain measure that there might be the areas susceptible to these processes, but individual treating of the factors or implementation of a mathematical model gives only a simplified image of what actually happens in a certain area. It is therefore a need for a validation of the simulation carried out on various environments and this validation may be performed by a geophysical method, used by TehSaufia et al. (2012) in studying the effects of piping and the erosion. For this study, we chose to carry out investigations with the Self Potential method.

This is a non-intrusive method that contributes to achieve, through subsequent methods, of an image of what is happening in the basement at a time (Revile and Jardani, 2013). It has direct applications in the mapping of the fluid leaking into the soil (Wishart et al., 2009; Moore et al., 2011; Boleve et al., 2011; Singarinbum et al., 2012). On the other hand, the physic-chemical approach of the method was performed by Linde et al. (2007), Boleve (2009), Revile et al. (2009), or Peksen et al., (2011).

The work of Jardani's et al. (2009) must also be specified, studying the level of phreatic water by this method, and the study of Giano et al. (2000) as well, which is focused on the analysis of sedimentary deposits through Self Potential method, the same type of deposits being found in the transition zone between the Dognecei Mountains and the Doclin Hills. This technique can be used in determining of the areas with susceptibility to erosion, even if in the first instance there are no visible elements. The 
representation of these processes can be made on a continuous structure like interpolating the values obtained from the field (Buhmann, 2000; Morse, 2005; Henglet al., 2008; Lu and Wong, 2008; Kleijnen, 2011) each interpolation method presenting some advantages and disadvantages.

The objective of this study is the analysis of the piping processes through a non-invasive geophysical method, at different time intervals and the correlation of these processes with the environmental factors.

\section{The study area}

The area in which investigations were conducted is located in northwestern of Caraș - Severin County, in the transition area between the Dognecei Mountains and the Doclin Hills at an altitude of $290 \mathrm{~m}$
(Fig. 1.), within the administrative boundary of the Doclin village, in the area of interfluve "Dealul Între Văi", at a distance about $2 \mathrm{~km}$ from the village. The investigations were carried out as a grid made in an area that has as lithology micaschists and paragneiss with biotite having the intercalations of micaceous quartzites or feldspathic quartzites from Proterozoic (Năstăseanu and Savu, 1968), lithological formations covered with pedological material.

The slope derived from a digital elevation model obtained from the interpolation of the contour lines on a topographic map with the scale 1:25.000 (Torok, 2001) is low, the area of interest being included in the class values below $10^{\circ}$, as attested and validated in the field, using a SUUNTO tandem compass. The declivity values were between 3 and $7^{\circ}$ in this case.

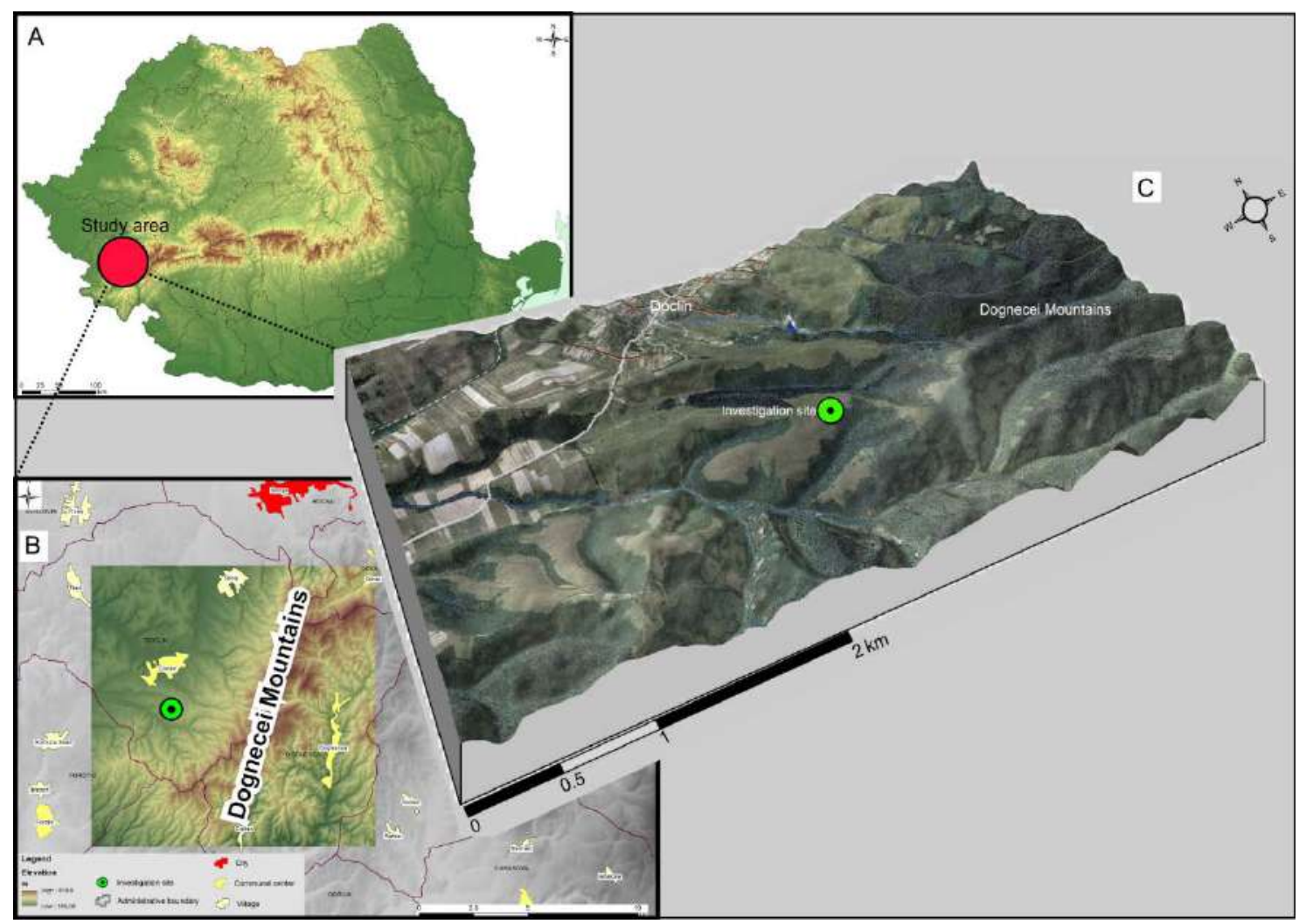

Figure 1 Location of the study area

The aspect of the area where investigations were made is SW and in some places west. This aspect influence the values obtained by the Self Potential method as a result of varying levels of reception of solar radiation.
The relief fragmentation depth is relatively low, of $57 \mathrm{~m}$, this value contributing to a reduced amount of water draining from the soil surface. In the north of "Dealul Între Văi" site, the gullies appear in the form of a bulb with variable lengths that can reach up to 150 meters, and in the mountain 
area, because of forestry practices, gullies and rills occurred, located predominantly near the forest roads.

The diversified climatic episodes contribute to shaping of the land surface by the intensity and the alternation of the rainfall (Rădoane et al., 2001), and by the average temperature and the amount of solar radiation at ground level that influence the process of evapotranspiration (Warsta et al., 2013). These factors contribute both directly and indirectly to the transport of the water and thus of the sediments at pore level, involving the erosion of subsurface (Warsta et al., 2013).

In this area there is no nearby weather station which can provide dates, and for knowing what kind of values appear here, we used the models of the annual average temperature and precipitation that were made based on specific values, yielding a linear regression equation, which is correlated with a DEM. The annual average temperatures, derived from this modeling, for the entire area, are included in the range from $11.2^{\circ} \mathrm{C}$ in areas with lower elevations and $8.6^{\circ} \mathrm{C}$ in the peak areas. The rainfall has values of about $750 \mathrm{~mm}$ in the lowlands and where the relief fragmentation is high, and about $900 \mathrm{~mm}$ in the central-northeastern area.

The model of the received radiation was derived based on the DEM with a spatial resolution of $10 \mathrm{~m}$ and is a tool for checking the amplitude of evapotranspiration phenomenon existing in different periods. It can be seen, therefore, that early autumn (15.09.2013, more precisely) (Fig. 2A), the amount of solar radiation was about $3274.9 \mathrm{Wh} / \mathrm{m}^{2} /$ day in the concerned area, compared to the solar radiation recorded in November, on 03.11.2013 (Fig. 2B), when the maximum is $1028 \mathrm{Wh} / \mathrm{m}^{2} /$ day. Basically, the solar radiation received by the ground during the late autumn days drops to $31 \%$ compared to the initial period. These differences contribute to the existence of different regimes of water movement in the soil, which influences the varied development of the erosion. The situation in the spring season shows a significant increase in the radiation received by the ground, with a maximum of 2268.8 $\mathrm{Wh} / \mathrm{m}^{2} /$ day, increasing by over 45 percent compared with 03.11 when measurements were made before the winter season. The main course of water from this area is Ciornovăţ creek, which is supplied by several springs, but predominantly from precipitation. In this area, a number of temporary water courses are active during periods of heavy rainfall, these contributing to increase of the soil erosion on slopes. The drainage of the volume of water resulting from the liquid and solid precipitation influence both surface erosion by moving unconsolidated fragments as well as the internal erosion through sustained action on the pores level. The woody species - especially Quercus sp. - are located around the area of investigation and sometimes meet shrub species such as hawthorn (Crataegus monogyna), rosehip (Rosa canina) or blackberry bush (Rubus fruticosus) (Anțilă, 2012), all occurring in the transition zone from the forest environment to that of the hills. The entire area comprises small grass associations (Poa nemoralis, Festuca ovina, Dactylis glomerata, Bromus secalinus) that contribute in a modest way to stabilize the soil because of the intense pastoral activity.

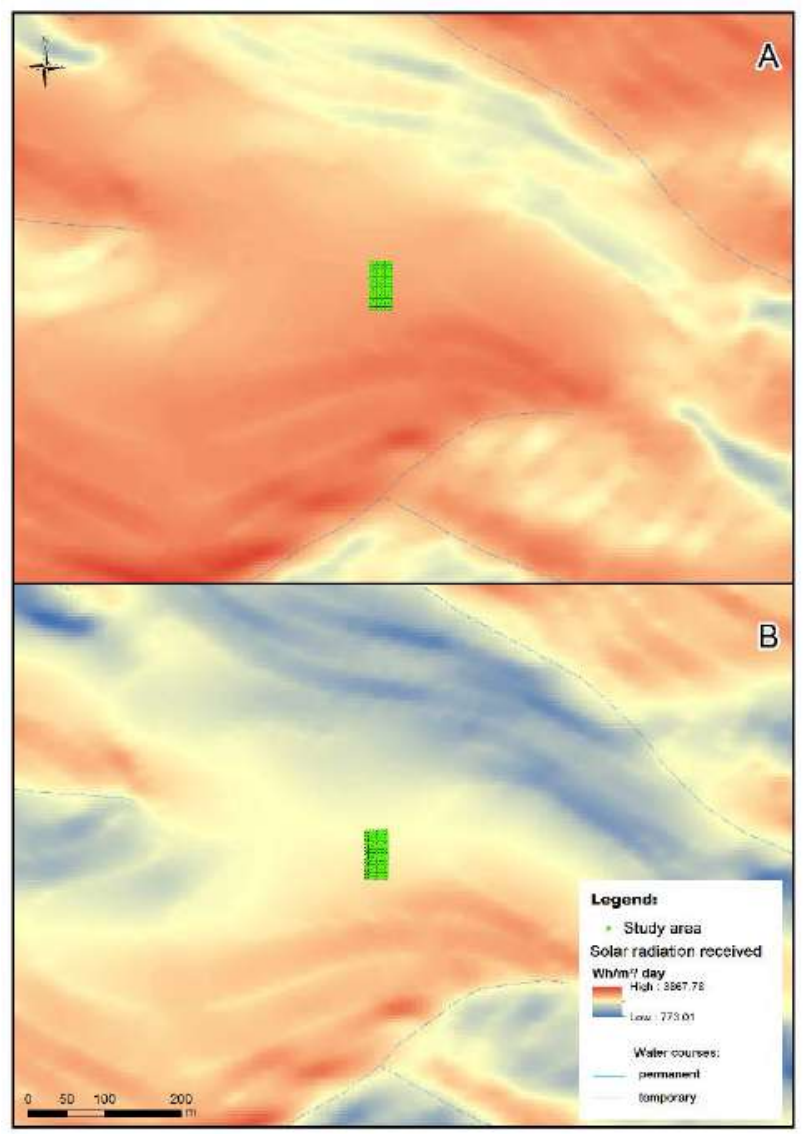

Figure 2 Simulated solar radiation in the interest area: $(A)$ 15.09.2013, (B) 03.11.2013 
The characteristics of the pedological material are important in the evolution of various forms of erosion, and therefore for the results obtained through Self Potential method as well due to the differentiated leakage of water through heterogeneous environments. A high proportion in the soil categories have it the districambosoils arranged in the eastern zone, which it corresponds to the mountain area, and being at the same time the area with the largest forest area expansion. For a more detailed analysis of the diagnostic properties of the soils in areas where investigations were conducted, we chose maps with the 50,000 scale of Ianoş and Pușcă, 1998. On large areas Luvisols can be found (pseudogley, local pseudogley, typical, eroded). In the eastern part of the Doclin village, the interfluves are composed from multiple types of alluvial-clay, presenting surface erosion caused by the water eroding in the "Dealul Între Văi" area and of the pastures located between the village and the forest area. In all these categories of soils, the piping is an active process (Bernatek-Jakiela, Poesen, 2018). The rock takes the form of middle fine-textured clays and the groundwater depth is over 10 meters.

The instrumental investigated area (Fig. 3) has a size of $25 \mathrm{~m}$ on the north and south sides - the grid has a NS orientation -, and $60 \mathrm{~m}$ on the east and west sides. The interval between sample points was $5 \mathrm{~m}$, with a fixed electrode placement to $3 \mathrm{~m}$ outdoors. The investigations were conducted on 09.15.2013, 03.11.2013 and 08.03.2014. If in the first period the horizon of soil was quite dry, in the last stage of investigation the soil was supersaturated and in the flat areas, the water is stagnating.

The analysis of the piping process involves the establishment of an investigation area in a place whose local gradient is lower. The woody vegetation must be reduced or non-existent because it serves to stabilize the soil and the amount of moisture in the soil must be high in some periods of the year. At those, the soil characteristics and his thickness are adding, because in some conditions, the response of the local lithology can be highlighted in the form of the cracks or the morphology, aspect that requires the knowledge of the local landscape for differentiation of the results. Based on these characteristics, we chose the location of the investiga- tion site within the upper area of the "Dealul Între Văi", where the land use is as meadows for grazing and the slope gradient is less than $10^{\circ}$. In the interval when the investigations were carried out, the amount of water in soil varied considerably, fact that emphasized the stress on soil.

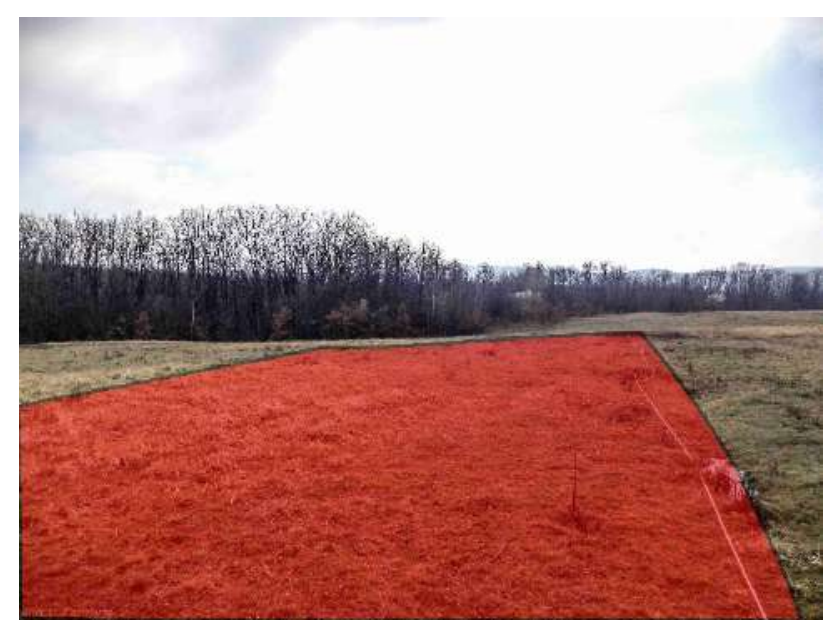

Figure 3 The investigation site „Dealul Între Văi", Doclin

\section{Methodological aspects}

\subsection{The Self Potential method}

The Self Potential Method is a non-invasive geophysical method of inquiry that allows obtaining natural values of the electric potential from the soil as a result of the chemical, physical and biological interaction of generating factors. Knowing the internal mechanisms that generate this electrical natural current can lead to a better interpretation of the results obtained, so that these processes will be presented in the following paragraphs.

The Self Potential is defined as "the passive measure in surface or in the drilling of the distribution of the electric natural potential created by the mechanisms of polarization of the electric loads in porous media (electro-infiltration related to water leakage, oxidation related to the redox phenomena)" (Jardani, 2007, p. 46).

The current recorded through the Self Potential method is regarded as having a source in the electrical double layer present as the contact area between a solid and a liquid state. This electric double layer implies that there is an area near the solids, called "compact Stern layer", from which they take loads of the mineral surface, and a concentration of 
mobile charges located in close proximity to mineral element (Fig. 4), called "Gouy-Chapman diffuse layer" (Boleve, 2009). The movement of the fluid in the pores of the soil contributes to movement of existing mobile ions, and when there is contact between the free colloids and the mobile part of the mineral layer, the latter is detached, helping to create convection current and another opposite called the conduction current. The potential associated with the conduction current is the one that can be measured at ground level (Moore et al., 2011).

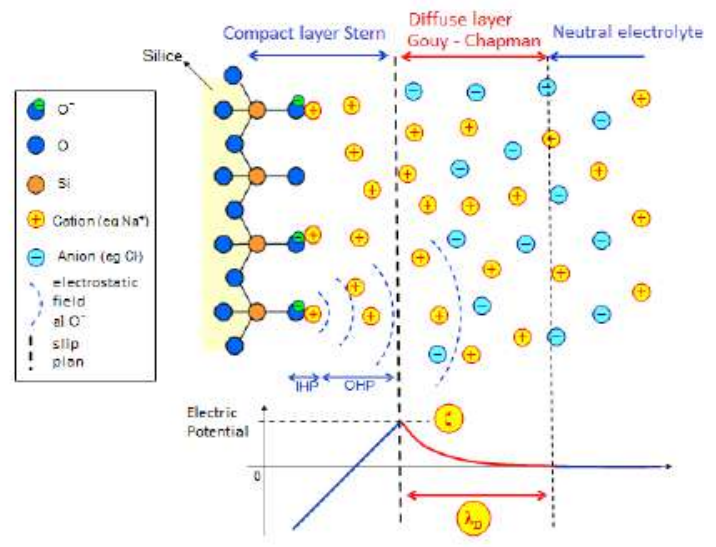

Figure 4 The ionic distribution diagram of the electric double layer in the case of a silicon surface (after Darnet, 2003)

It has been observed that the excess of charges existing in the diffuse layer moves toward the end of the sample, in the case of fluid displacement in the poral environment. The movement of electric charge is called the electric current source (convection current) and generates an electric field that can be recorded by the devices (Boleve, 2009). It occurs complementary a conduction current generated by charges induced by electro-infiltration, opposite in the sense of the convection current. The intensity of conduction current depends mainly on the electrical conductivity of the environment under which the process is carried out (Boleve, 2009), the poral environments contributing to the generation of an electric conduction current more important. The electric potential difference between the terminals of electrodes is called the electro-infiltration potential.

Equally important is how the electric potential distribution is segmented, appearing two aspects like: one refers to a primary source associated with the difference in charges of the natural current density, this source is responsible for the appearance of the electric field measurable in the area around a location and, the second, refers to the secondary sources, which appear in addition to electric fields associated with the primary source, where heterogeneity of the electrical resistivity is responsible for the disruption of the distribution of electric potential; this disturbance can be represented as an accumulation of electric charges in the heterogeneous areas (Jardani, 2007). Due to delineation in the soil of the processes through which the electro-infiltration current is generated, the characteristics of the pedological material are influenced by many factors (geology, plant associations (even if the radicular system is limited to the first centimeters of the upper horizon of the soil, these plants compensated by density, so it is recommended to conduct investigations in periods when their development is minimal), climatic influences, moisture found in soil; geomorphometry and the Self Potential values obtained can be influenced by all these factors. In addition to the electro-infiltration current itself there are also associated a range of parameters that influence positive or negative values recorded.

Although it has a multitude of applications, this method does not present a great interest for some researchers because of the electrical noise and difficulties of interpretation. Such noise sources come in the form of telluric currents, the movement of the electrodes, of the topographic effect associated to the potential difference, of the photovoltaic potential or of the changes incurred in the composition and the moisture of the soil and of its plant cover (Nyquist and Corry, 2002). The noise sources can have both natural character (Sheffer, 2007; Jardani, 2007; Guichet, 2007) and anthropogenic (Nyquist and Corry, 2002). The latter can occur in the form of terrestrial power grids or underground, of the buried metal objects or even of the devices used by an analyst (some influences may occur due to the cables between the electrode and the voltmeter, for example). If the anthropogenic noise generating sources can be identified and possibly avoided, the same cannot be said about the natural sources. Jardani (2007) identified as being responsible for producing of the noise the following two sources, 
namely the magneto-telluric induction and the bioelectric potential. This effect is well highlighted in the forest areas and those with pastures and meadows, due to the plant roots which drain water from the soil thus helping to create an additional electric potential, but this effect can be diminished and/or eliminated by using bentonite for the homogenization of the moisture in the sample points. According to the company that produces the SDEC electrodes (electrodes used in this study) the temperature electro-infiltration current ratio is $0.21 \mathrm{mV} /{ }^{\circ} \mathrm{C}$, so that during the day, the thermal amplitude should also be considered and off-setting from the final values. A difference of $10^{\circ} \mathrm{C}$ is considered to be responsible for the amplitude of Self Potential values of about $2 \mathrm{mV}$, an aspect which should be corrected (Jardani et al., 2009).

In addition to the noise sources listed, changes in Self Potential values are influenced by the effect of $\mathrm{pH}$, the more alkaline it is, the recorded values are higher on the negative scale (Ishido and Mizutani, 1981, quoted by Guichet, 2007). The rock mineralogy also imposes certain issues, depending on their composition the electro-infiltration differentiated values are obtained. Equally important are the influence of the permeability, partial saturation of the electrolyte or the soil electrical conductivity (Darnet, 2003). Knowledge of these parameters allows an objective distinction between current source itself and those that are redundant and contribute to a misinterpretation of results (Urdea and Țambriș, 2014).

\subsection{The data acquisition}

The Self Potential investigations were carried out using the non-polarized electrodes connected to a voltmeter (Fig. 5). A non-polarized electrode is composed of a metal in contact with a saline solution (Revile, Jardani, 2013), in this case the Petiau electrodes $\mathrm{Pb} / \mathrm{Cl} 2$ in tandem are used: one used as a fixed electrode (placed outside the site investigation), and a second movable electrode displaced at different sample points. At the point where the fixed electrode was placed, bentonite mixed with water was inserted for better conductivity and for avoid reducing of the salinity from the poral water due to the evapotranspiration occurred at the soil level as a result of the changes made by the analyst (Revile, Jardani, 2013).

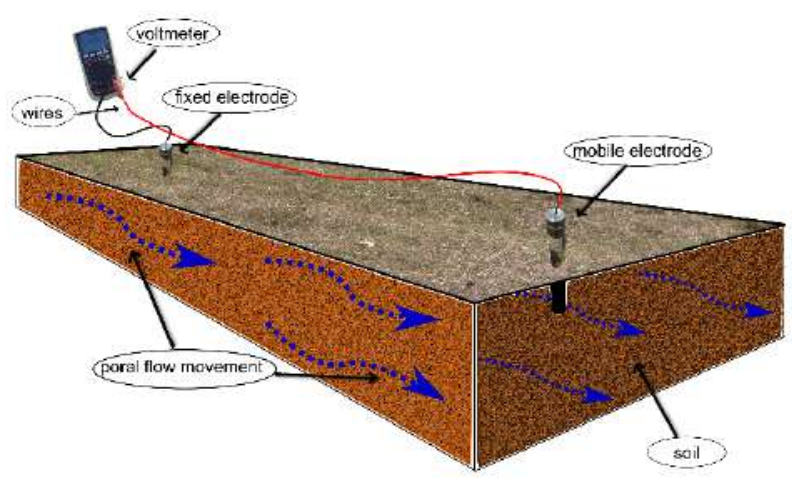

Figure 5 The model of data acquisition of Self Potential values

The voltmeter used was a Voltcraft VC850 which allows the recording of the voltage of the electric current in the range of $0.1 \mathrm{mV}-1000 \mathrm{~V}$, thus providing high accuracy values. The instrument can also be used for the acquisition of the temperature values and the intensity and frequency of the current out of the soil. With these tools available, we chose to obtain values from a rectangular network, practice that allowed the resumption of investigations in the same point after a period of time.

\subsection{The interpolation of values obtained by Self Potential method}

The next step of data acquisition was to use them in a way that allows continuous analysis of the values obtained in the grids made and their modeling as objective to obtain patterns of erosion and water infiltration into the soil (Urdea and Tambriș, 2014). This operation was carried out by integrating those values in the interpolation methods implemented in the software ArcMap 10.1. Within ArcMap 10.1 software, there were implemented several interpolation methods, both deterministic, such as Inverse Distance Weighting, Global Polynomial Interpolation, Radial Basis Functions and Local Polynomial Interpolation, as well as stochastic called geostatistical methods (A quick tour of Geostatistical Analyst, ArcMap 10.1). However, in both categories of interpolation methods, there are interpolations that return results that take into account the values entered previously with an intersection between the 
result and the sample values, these being of accurate type. On the other hand, there are also interpolations that simulate the result starting from the initial values and applying a smoothing over them, the latter being known as inaccurate methods (Urdea and Tambriș, 2014).

For this study, we chose the use of accurate interpolations, given that it operates directly with the values resulting from investigations in small areas. The study was based on the use of the Radial Basis Functions (RBF) Interpolation (Fig. 6.), but other interpolation models can be used. In this method, the resulting surface must pass through every sample point, the spaces between the points being constructed on the basis of some variables selected by analyst: Thin-plate Spline, Spline with tension, Completely regularized Spline, Multiquadric function and Inverse multiquadric function, the last function resulting in a much lower prediction error compared to the others. This method was used in this study also because of the favorable response to all data sets, compared with other models that returned the artifacts to some integrated data sets. Another interpolation methods which presents potential for use are Inverse Distance Weighted (IDW) (Childs, 2004), (Fig. 6.) or Kriging. Under these conditions, it was necessary to use a method in which the analyst intervened as little as possible to not significantly influence the results. Also, the method used had to take into account the values entered, since there may be cases when isolated values can explain certain particularities of the environment, values that return the least square mean error.

Thus we choose to use in this study Radial Basis Functions interpolation method, which offers standardization for all data sets included in the returned raster data.

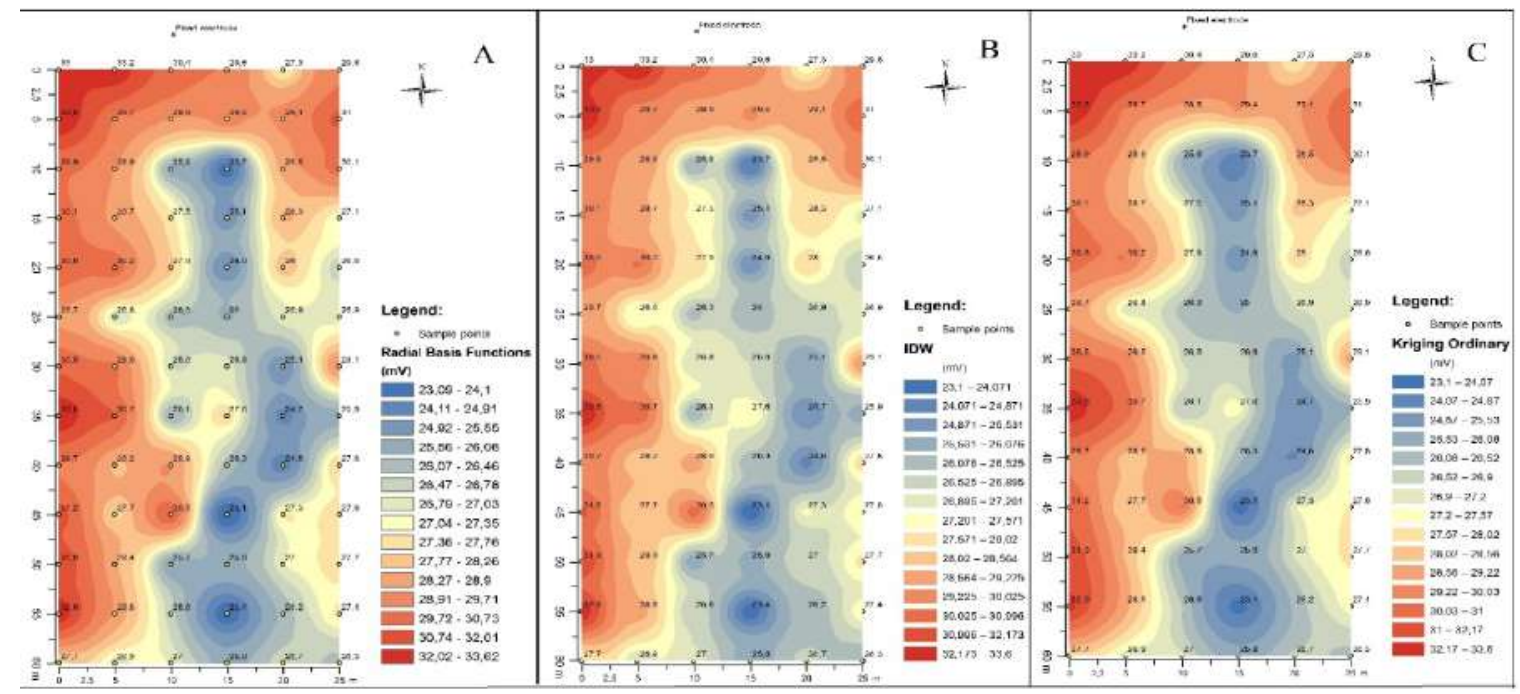

Figure 6 The SP values interpolation for investigation site „Dealul Între Văi” - stage III. A. the IDW method; B. the RBF method; $C$. the Kriging Ordinary method

\subsubsection{Defining the parameters used in the interpola- tion method}

In the Radial Basis Functions method there are some parameters which must be defined to obtain a reduced mean square error (RMSE), (Table 1). We defined some parameters for all the data sets with some exceptions when we let the custom settings. These parameters were determined after testing of multiple combinations. In Geostatistical Analyst module, in the first phase, the selection of the data set and of the values that were to be used was made and after, the parameters were defined in the "Method Properties" section (Fig. 7). In the section "General properties", we choose the function that is to be used and, based on this a different RMSwas returned, based on the algorithm implemented in the tool.

Based on the data set obtained in the investigation site "Dealul Între Văi", in the first stage of measurements, without changing the other parameters, it resulted the following mean square error 
(Table 1) and from these models, it can be seen that the Inverse Multiquadric method returned the lowest mean square error. When a function is chosen, below the row of choice of the function it appears a parameter which acts as weight and is directly influenced by the selected function and of the characteristics of the data set. After these steps, it is established the way of finding the neighbors based on which will be realized and the return of the intermediate values.

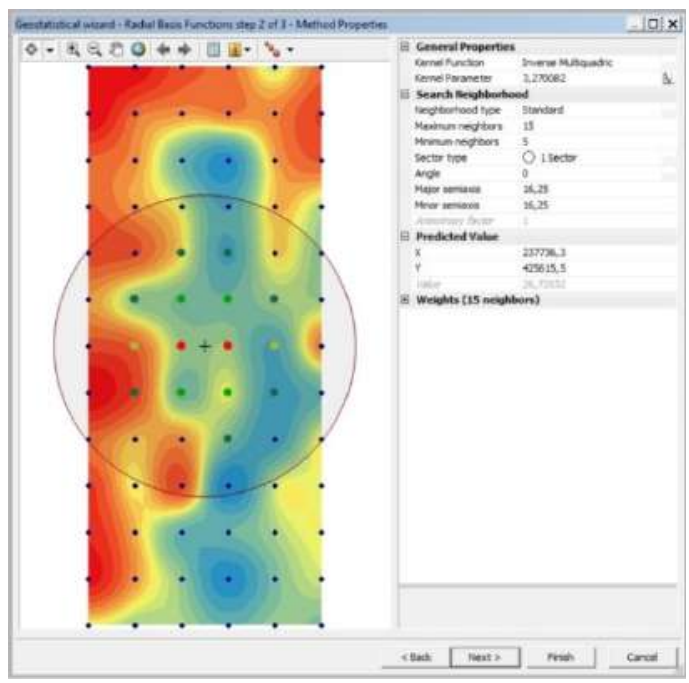

Figure 7 Defining the parameters of the interpolation model in the Geostatistical Analyst module

Table 1 The comparison of the RMS for the interpolation models used

\begin{tabular}{|l|c|}
\hline Function & RMS \\
\hline CompletelyRegularizes Spline & 1.55 \\
\hline Spline withTension & 1.56 \\
\hline Multiquadratic & 1.57 \\
\hline Inverse Multiquadratic & 1.54 \\
\hline Thin Plate Spline & 1.69 \\
\hline
\end{tabular}

Each different setting of the interpolations parameters affects the final result, but it should be kept in mind that these settings should be implemented in each of the data sets, and they must be chosen in such a way that they do not differ.

\section{Results}

The investigation was carried out in the form of three periods of analysis on the area of interest, so that the geomorphological features under study, namely the piping phenomenon, to be observed.
Thus, in the first stage of investigation, performed on 15.09.2013 (Fig. 8), grid made after a period with low rainfall, the soil was quite dry on the first centimeters of the profile due to the significant evapotranspiration in the higher temperatures conditions. However, the existing soil moisture was sufficient to report negative values mostly, associated with a sufficient fluid mobility. The areas with the largest displacement of water in the soil can be seen in the eastern part of the grid, an area characterized by an increase in the slope gradient of up to $7^{\circ}$. It should be mentioned that in the southern part of the study area, at a distance that varies between 25 and $40 \mathrm{~m}$, depending on the corners of the grid, the forest area begins, aspect that can contribute to the modification of the obtained values.

Isolated, distinct portions appear in which a localized movement of water in soil results, as is the case of portions between the points of 10 to $15 \mathrm{~m}$ on the vertical axis and $10 \mathrm{~m}$ on the horizontal axis. Even under these conditions, a drainage trace can be observed on the eastern side, over $45 \mathrm{~m}$ long. There, the values recorded at that time were between -8.9 mV and -18.2 mV (Fig. 8).

The sections with higher values (above $4 \mathrm{mV}$ ), are located mainly in the N, NW and SW area, corresponding to the lower slope areas. This time, the amplitude of returning values is higher $(23.97 \mathrm{mV}$ ) compared to other periods in which investigations were conducted. The lack of a regular flow of water in the soil is highlighted from the model obtained by interpolation of the Self Potential values as well, and there is not, at this time, outlined a well-defined linear sub-cutaneous flow of drainage.

In the second stage of the investigation, on 03.11.2013 (Fig. 8.), the soil moisture was higher, and although the values obtained were all positive between $8.4 \mathrm{mV}$ and $19.2 \mathrm{mV}$-, associated with a lack of mobility of water, this can be attributed to the saturation of soil with pore water. Even if the values returned are higher (positive) than in the first stage of investigation, it is not about a significant changing of the values in the positive interval, usually associated with the stability of the fluid. Also, in this case, higher values are located in the NE, NW and $E$ of the grid, being the portions that appear to be most stable in terms of fluid dynamics. 
URDEA and ȚAMBRIȘ / Revista de Geomorfologie 21 (2019)

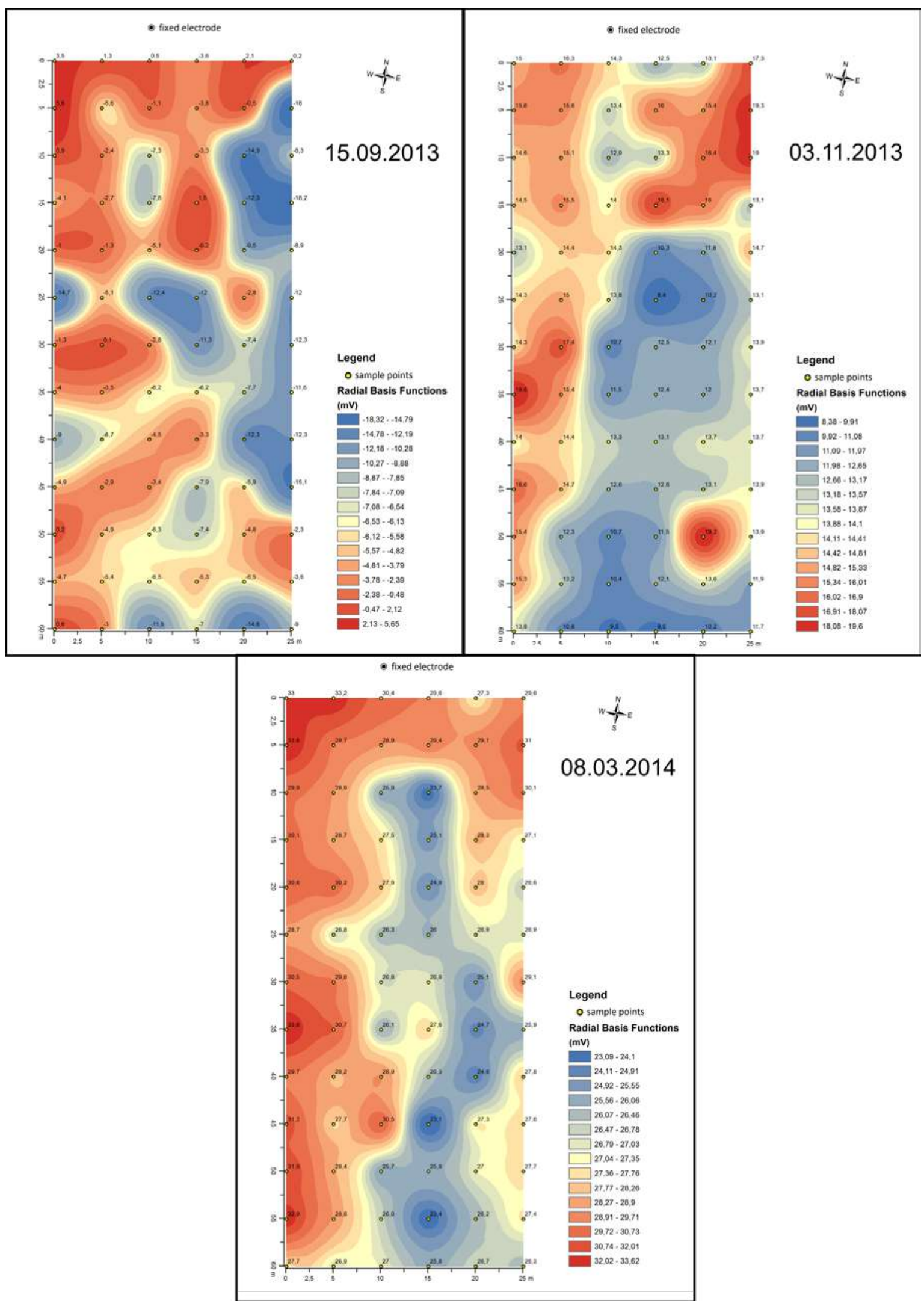

Figure 8 The SP model on the site „Dealul Între Văi” 
Although the values recorded were higher than in the previous stage, their spatial distribution outlines better the existence of an underground drainage discrete channels network. It is oriented $\mathrm{N}-\mathrm{E}$, between the sample points from 5 and $20 \mathrm{~m}$ on the horizontal axis and the 20 and $60 \mathrm{~m}$ on the vertical axis. Given the fact that the soil layer is relatively consistent, with no rock fragments on the surface, the entire area having the flat features, this drainage channel could, mapped through the Self Potential method, to be tied to lithologic substrate as well, thus contributing to the manifestation of subsurface erosion.

The third stage of the investigation was conducted in early spring, on 08.03.2014. This time, although the solid winter precipitation were reduced quantitatively in the context of southern orientation of the area of analysis, with an amount of solar radiation by up to $2500 \mathrm{Wh} / \mathrm{m} 2 /$ day, due to the characteristics of the flat topography, the soil moisture was raised. The poor drainage of surface water due to low gradient led to its super-saturation in some sampling locations and the water stagnation occurred. For these reasons, the peripheral areas of the grid, except for the south of it, present high levels of Self Potential values, up to $33.6 \mathrm{mV}$ (Fig. 8.), much higher than in the previous stage of measurements, when the maximum was $19.6 \mathrm{mV}$. The presence of the positive values confirms the sustained reduction in fluid flow mobility, and the lack of the shrub and tree vegetation favors the registration of values consistent with what was happening at that time in the soil layer.

The cause of this difference between the positive values perceived by the voltmeter and the shape of drainage channel from the interpolation of these values is represented by the slope that is low, but in the conditions of soil saturation in the sides of the grid, the pore water is concentrated in the middle of it, having a slope a few degrees higher than the rest of the site of interest.

In terms of topographical uniformity, the identification of a linear drainage network would indicate, in our opinion, a differentiation in horizons of the deeper soil texture or a discontinuity in crystalline schists microfabrics, which is the parental material, or even a major schistosity plan or a hidden discrete fault.

In all three stages of investigation, at the level of column 4 (points located on the vertical axis at 15 $\mathrm{m}$ from the west side of the grid), higher values were obtained in the upper zone (Fig. 9) and lower values in the lower part of the grid, the tendency of displacement of the water within the drainage channel being affirmed.

Analyzing the Self Potential data, we can observe well-defined fluid flow on the $\mathrm{N}-\mathrm{S}$ direction, confirming its existence during the three stages of investigation, meaning that this area is prone to piping process.

\section{Discussions}

The Self Potential method, through the simplicity it offers to create the prerequisites to achieving a model of water movement in soil under the action of various endogenous and exogenous factors, it has the role to highlight the fluid mobility in the first phase. Even if the Self Potential value returns were influenced by a variety of factors, each of them has different weights in the resulting values, so it is difficult to quantify their importance in the absence of objective studies on them. The main problem is related to the lack of climatic data, to which are added the characteristics of soils and geology, which are the most important for this analysis. For example, it requires knowledge of soil moisture, this being one of the factors that directly affects the fluid mobility, or the physics of movement processes of the sedimentary materials in the regolith basement. The processes and factors from soil surface are easier to interpret, having an important role in erosion processes. However, a degree of uncertainty occurs related to assessing the extent to which some changes in the obtained values are generated. The degree of detail requires consideration of additional factors, so at a small scale of detail some indicators will be lost from analysis while, at a greater detail scale, the correlation with overall factors is more difficult. 


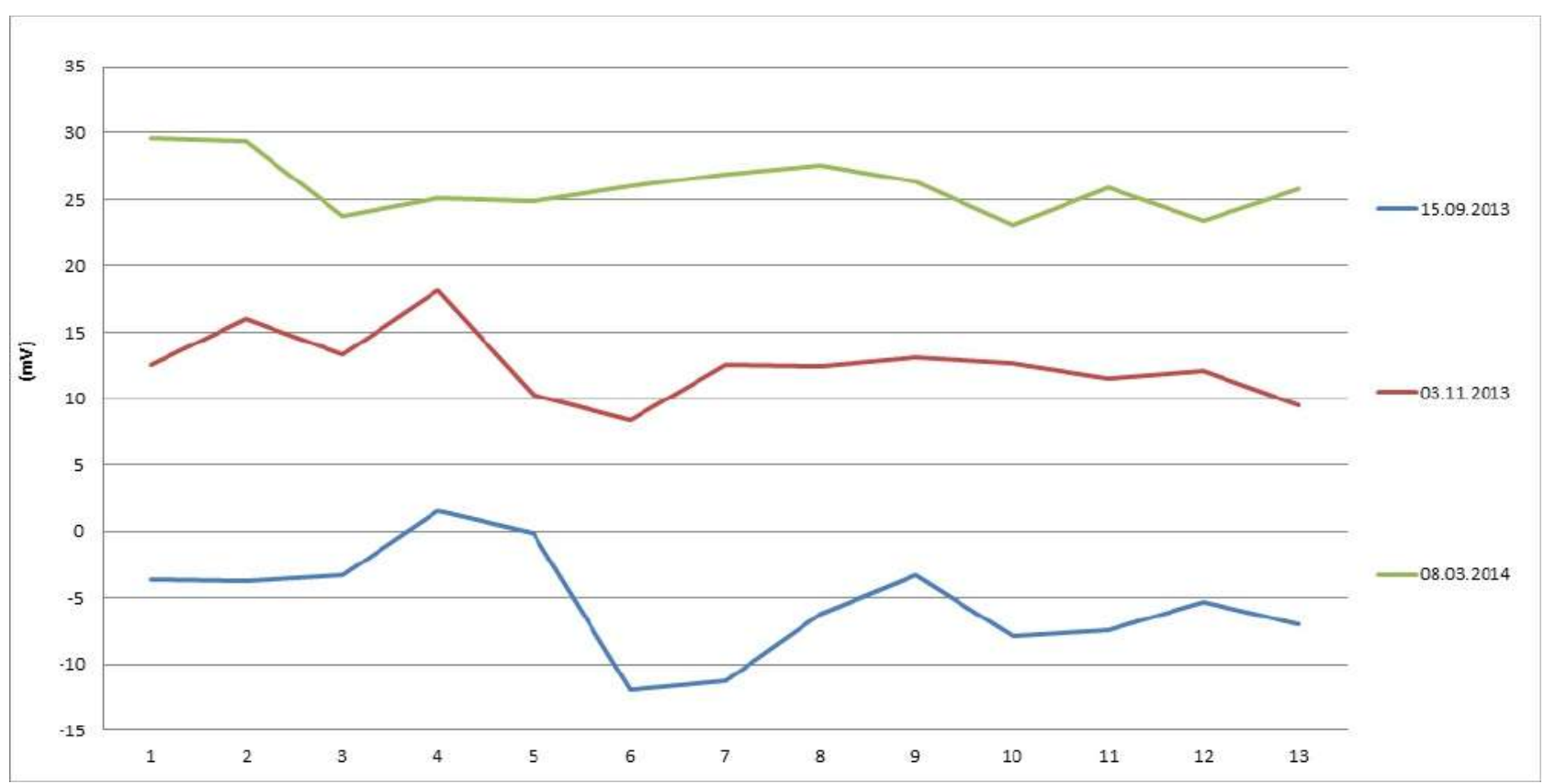

Figure 9 The SP profile - column 4, site „Dealul Între Văi”, periods: a.15.09.2014; b. 03.11.2013; c. 08.03.2014

For observing the behavior of the analyzed process, the multi temporal analysis of the study area was used. The resulting Self Potential model in a certain period can be influenced by local factors which can occur only in that interval of time, as it happened on this study area. The increasing of the amount of soil water contributed to the formation of internal drainage channel, and decrease of the pores water minimizes the footprint of the linear voids formed by the piping process. In addition to changes related to the influence of natural and anthropogenic factors on the ground, changes due to the modeling of the analyst were imposed, most often related to the representation of the model results.

The sampled values can remain the same, but the types of classification condition the type of interpretation performed by the analyst, especially that, by making models at different time intervals, it may contribute to the preservation of the Self Potential values in certain conditions, but with a different distribution of these values. The thinking of a uniform methodology for achieving all the models through interpolation methods will have two different effects: on the one hand, the same settings will be applied to all models, which will reduce the bias in their creation, but on the other hand, it will contribute at increase the mean square error for some models built and at these it will need to apply specific modifications. The multitude of factors causing influences of any kind imposed a detailed knowledge of themselves, although the technique used in some circumstances contributed to the generation of artifacts, particularly from the cables by which electrical current was transmitted between electrodes and voltmeter. However, these problems have been correctable, and some influences, like those caused by thermal amplitude in a day or those induced by vegetation can be deduced and corrected.

The accurate establishing of the soil moisture, the quantification of the vegetation impact on the results, the reduction of the influence caused by bioelectricity, and climatic gradient within a day by mathematical methods, the knowledge of the soil layer depth, this can be achieved through GPR and/or ERT techniques, or analyses under laboratory conditions of some models to be applied in the natural environment could be some of the next trends for the results optimization and the modeling of Self Potential values.

Equally important it would be an extension of the recording technology of the values in question by using several electrodes that provide real-time information about what is happening in the soil. On the side of the computer analysis, it is required the 
thinking of the integration and modeling some parameters to return a high degree of accuracy and to suit various conditions as to exclude certain anomalies.

\section{Conclusions}

The applying of Self Potential method to the knowledge of the piping phenomenon is, according to our information, a premiere for the geomorphological literature. Considering the specificity of the method but also the characteristics of the test area, we consider the results to be promising. The analysis of the results was correlated with the analysis of the methods of interpolation and graphical representation, so that, in our opinion, the method that best expresses the territorial differences of the subcutaneous drainage and the manifestation of the piping phenomenon is the Radial Basis Function method. The fact that the results were obtained through investigations carried out in three distinct periods, each of them having an "own imprint", constitutes as a validation of the application of the method to this phenomenon. We consider that the application, in parallel, with other complementary geophysical methods, such as electric tomography (ERT), along with the knowledge of soil characteristics and the geological substrate, as well as meteorological and topoclimatic parameters would lead to a better understanding of this phenomenon.

\section{References}

Alewell C, Meusburger K, Brodbeck M, Bänninger D. 2008. Methods to describe and predict soil erosion in mountain regions. Landscape and Urban Planning, 88: 46-53.

Anthony J, Jones A. 2004. Pipe and piping. Encyclopedia of Geomorphology, Vol. 2. Routledge Ltd., New York, 784-788.

Anțilă O. 2012. Cercetări privind condițiile de producere și conducere a regenerării arboretelor din șleaurile de deal cu gorun și cer din Masivul Dognecea. Centrul de cercetare: Managementul durabil al Resurselor Forestiere și Cinegetice, Brașov, 22 p.

Bernatek-Jakiela A, Poesen J. 2018. Subsurface erosion by soil piping: significance and research needs. Earth-SCience Reviews, 185: 1107-1128.

Boleve A. 2009. Localisation et quantification des zones de fuites dans les digues et les barrages par la méthode du potentiel spontané. PhThesis, Université de Savoie, Savoie, $223 \mathrm{p}$.

Boleve A, Janod F, Revil A, Lafon A, Fry J. 2011. Localization and quantification of leakages in dams using time-lapse self-potential measurements associated with salt tracer injection. Journal of Hydrology, 403: 242-252.

Bonelli S, Benahmed N. 2010. Piping flow erosion in water retaining structures: inferring erosion rates from whole erosion tests and quantifying the failure time. IECS 2010, 8th ICOLD European Club Symposium Dam Safety - Sustainability in a Changing Environment, Innsbruck: Austria, 6 p. fhal-00555648f.

Buhmann MD. 2000. Radial Basis Functions. Cambridge University Press, $38 \mathrm{p}$.

Colangelo G, Lapenna V, Peronne A, Piscitelli S, Telesca L. 2006. 2D Self-Potential tomographies for study in groundwater flows in the Varco d'Izzo landslide (Basilicata, southern Italy). Engineering Geology, 88: 274-286.

Darnet M. 2003. Caractérisation et suivi de circulation des fluides par la mesure de Potentielles Spontanés (PS). $\mathrm{PhD}$ Thesis, I'Université Louis Pasteur, Strasbourg I, $205 \mathrm{p}$.

Flores-Berrones R, Lopez-Acosta N. 2011. Internal erosion due to water flow through earth dams and Earth Structures. InTech, Rijeka, 283-307.

Giano S, Lapenna V, Piscitelii S, Schiattarella M. 2000. Electrical imaging and self-potential surveys to study the geological setting of the Quaternary slope deposits in the Agri high valley (Southern Italy). Annali di Geofisica, 43(2): 409-419.

Golse F. 2011. From the Boltzmann equation to hydrodynamic equation in thin layers. Bolettino delle Unione Matematica Italiana, 163-186.

Guichet X. 2002. Etudes expérimentales des propriétés électriques des roches potentielles d'électro-infiltration, suivi des mouvements de fluides en zones hydrothermales. PhD Thesis, Université Paris 7, Paris, $199 \mathrm{p}$.

Ianoș G, Pușcă I. 1998. Solurile Banatului. Edit. Mirton, Timișoara, $106 \mathrm{p}$.

Jacobson T. 2013. An analysis on soil properties on predicting critical hydraulic gradients for piping progression in sandy soils. Utah State University, All Graduate Plan B and other Reports. Paper 336, 38 p.

Jardani A. 2007. Nouvelles approches géophysiques pour l'identification des dolines et des cavités souterraines dans un contexte karstique. PhD Thesis, Université de Rouen, Rouen, 225 p.

Jardani A, Revil A, Barrash W, Crespy A, Rizzo E, Straface S, Malama B, Cardiff M, Miller C, Johnson T. 2009. Recon- 
struction of the Water Table from Self-Potential Data: A Bayesian Approach. Ground Water, 47(2): 213-227.

Linde N, Revil A, Boleve A, Dage C, Castermant J, Suski B, Voltz M. 2007. Estimation of the water table throughout a catchment using self-potential and piezometric data in a Bayesian framework. Journal of Hydrology, 334: 88- 98.

Maineult A. 2004. Application de la méthode du potentiel spontané a l'hydrogéologie: expérimentation sur modèle réduit d'aquifère. $\mathrm{PhD}$ Thesis, Université de Savoie, Savoie, 216 p.

Marinică I, Borza I. 2010. Impactul exploatărilor de zăcăminte metalifere asupra calității apei în județul Caraș Severin. Instit. Naț. de Hidrologie și Gospodărirea Apelor, Conf. St. Jubiliară 256-267.

Mears BJr. 1968. Piping, in Fairbridge. RW (editor) - The Encyclopedia of Geomorphology, Ed. Reinhold, New York, 849-450.

Medeleț F. 2005. Date din istoria comunei Doclin. AnaleleBanatului, XII-XIII: 513-522.

Mehanee S. 2014. An efficient regularized inversion approach for self-potential data interpretation of ore exploration using a mix of logarithmic and non-logarithmic model parameters. Ore Geology Reviews, 57: 87-115.

Moore JR, Boleve A, Sanders JW, Glaser SD. 2011. Selfpotential investigation of moraine dam seepage. Journal of Applied Geophysics, 74: 277-286.

Năstăseanu S, Savu H. 1968. Notă explicativă Harta Geologică, Scara 1:200.000, foaia L-34-XXVIII, Institutul Geologic, Bucureşti.

Nunes A, De Almeida AC, Coelho C. 2011. Impacts of land use and cover type on runoff and soil erosion in a marginal area of Portugal. Applied Geography, 31: 687-699.

Nyquist J, Corry C. 2002. Self-potential: the ugly duckling of environmental geophysics. The Leading Edge (Society of Exploration Geophysicists), 446-451.

Peksen E, Yas T, Kayman AY, Ozkan C. 2011. Application of particle swarm optimization on self-potential data. Journal of Applied Geophysics, 75: 305-318.

Rădoane M, Dumitru D, Ichim I. 2001. Geomorfologie. Edit. Universității Suceava, 394 p.

Revil A, Jardani A. 2013. The Self-Potential Method: Theory and Applications in Environmental Geosciences. Cambridge University Press, Cambridge, 369 p.

Revil A, Trolard F, Bourrie G, Castermant J, Jardani A, Mendonca CA. 2009. Ionic contribution to the selfpotential signals associated with a redox front. Journal of Contaminant Hydrology, 09: 27-39.

Richard KS, Raddy KR. 2007. Critical appraisal of piping phenomena in earth dams. Bull. Eng., Geol., Environ., 66: 381-402.
Roudasari M, Beitollahi A. 2013. Forward modeling and inversion of self-potential anomalies caused by 2D inclined sheets. Exploration Geophysics, 44: 176-184.

Schuppener B. 2013. Hydraulic failure. Geotehnical Design, Dublin, $37 \mathrm{p}$.

Sencu V, Ianoș I. 1987. Munții Dognecei, în Geografia României, III. Edit. Academiei Române, București, 392-393.

Sheffer M. 2007. Forward modelling and inversion of streaming potential for the interpretation of hydraulic conditions from self-potential. PhD Thesis, The University of British Columbia, Vancouver, $224 \mathrm{p}$.

Singarimbun A, Djamal M, Meilawati F. 2012. Fluid Flow Direction Beneath Geothermal Area Based on SelfPotential Data (A Case Study at Mount Patuha, West Java, Indonesia). International Journal of Geolog, 1/6: 26-35.

Straface S, De Biase M. 2013. Estimation of longitudinal dispersivity in a porous medium using self-potential signals. Journal of Hydrology, 505:163-171.

TehSaufia A, Saad R, Nordiana M. 2012. Integration of Electrical Imaging Methods in Detecting Engineering Problems. Intern. Conf. on Geological and Environmental Sciences IPCBEE, 3/6, IACSIT Press, Singapore.

Torok-Oance M. 2001-2002. Aplicații ale SIG în geomorfologie (I). Realizarea modelului numeric al terenului și calcularea unor elemente de morfometrie. An. Universităţii de Vest din Timişoara, GEOGRAFIE, XI-XII: 1730.

Verachtert E, Van Den Eeckhaut M, Poesen J, Govers G, Deckers J. 2011. Prediction of spatial patterns of collapsed pipes in loess-derived soils in a temperate humid climate using logistic regression. Geomorphology, 130:185-196.

Urdea P, Tambriș A. 2014. Spontaneous Potential investigations in Semenic Mountains. STUDIA UBB GEOGRAPHIA, LIX, 2: 25-46.

Warsta L, Taskinen A, Koivusalo $\mathrm{H}$, Paasonen-Kivekas $\mathrm{M}$, Karvonen T. 2013. Modelling soil erosion in a clayey, subsurface-drained agricultural field with a three-dimensional FLUSH model. Journal of Hydrology, 498: 132-143.

Wishart DN, Slater LD, Schnell DL, Herman GC. 2009. Hydraulic anisotropy characterization of pneumatic fractured sediments using azimuthal self-potential gradient. Journal of Contaminant Hydrology, 103: 134-144.

*** A quick tour of Geostatistical Analyst, ArcMap 10.1.

*** ANCPI - Ortofotograme - 2005

*** ArcGis 10.1 Help.

*** Soil Map of Romania 1:200.000, (1989), (sheet Reșița), Research Institute for Pedology and Agrochemistry.

*** Topographic Map 1:25.000, sheet L-34-104-A-b. 
*** Institute of Geology and Geophysics - Geologic Map 1:200.000, sheet L-34-XXVIII.

*** The Annual Report concerning status of environmental factors from Region 5 West in 2010;

http://rezervatii.exploratorii.ro/rez11.php.

http://www.sdec-france.com/soil-science-equipment-sensor-pms9000.html.
http://www.conrad.com/ce/en/product/124602/VOLTCRAFT-VC850-Digital-Multimeter-with-Software-included-6000-counts-CAT-IV-600V-CAT-III-1000V.

http://individual.utoronto.ca/lackner/ggr272/DataClassificationMethods.pdf.

http://blogs.esri.com/esri/arcgis/2007/10/18/about-thegeometrical-interval-classification-method. 